\title{
Exploration on Practical Teaching of Radio and TV Directing in the Background of University Transformation
}

\author{
Wang Xiaolei ${ }^{1, a}$ \\ ${ }^{1}$ Baicheng Normal College, Media Institute, Baicheng, Jilin \\ awangxiaolei1979@163.com
}

Keywords: Transformation and development; Local colleges and universities; Practice teaching

\begin{abstract}
The application of undergraduate colleges is the focus of the transformation and development of colleges and universities. It is necessary to realize the goal of transformation and development, and to cultivate the talents and talents needed by the society. Practical teaching plays a decisive role in the cultivation of applied talents. Radio and television director professional as a new professional, practical teaching link is very weak, has not yet formed a complete system. In this context, based on the deep analysis of the problems in the practical teaching of radio and television, the paper puts forward the countermeasures for the development of practical teaching for the cultivation of applied talents, and provides the reform and design of the practice teaching system of local undergraduate colleges in the background of transformation reference.
\end{abstract}

\section{Introduction}

Local colleges and universities to apply technology-based transformation has become a social consensus. Cultivating and applying high - tech talents is the key to local economic development and social progress. Practical teaching plays a decisive role in the cultivation of applied technology talents, but there are many problems in the practice teaching of colleges and universities in many places in our country. Under the background of the transformation of local colleges and universities, we must adopt various policies to strengthen the construction of practical teaching in colleges and universities.

"Local colleges and universities" is aimed at the ordinary colleges and universities that have been promoted to undergraduate colleges since 1999, that is, "to guide a group of ordinary undergraduate colleges to apply to the transformation of applied technology colleges and universities", to serve the local economy and cultivate the talents needed by the society. Baicheng Teachers College was identified as one of the 9 provincial-level overall transformation and development of pilot colleges and universities. Radio and television director of professional (referred to as radio and professional) is the rise in recent years in the art, music, professional and other categories of higher art education, radio and television professional is a new professional, the theory and practice in line with very close professional, Mainly for all levels of television, radio, television program production units, film production and distribution agencies, network media companies and other film and television media units to cultivate the application of specialized personnel.

\section{The Importance of Practical Teaching in the Training of Radio and TV Directing Talents}

Practical teaching is an important teaching link in colleges and universities, with a pivotal role. And the local colleges and universities to implement the transformation and development of its personnel training system must be adjusted accordingly, the practice of teaching is bound to adapt to the application of technical requirements, innovation and development in order to better promote personnel training and local economic development, social progress.

The transformation of local colleges and universities into applied technology colleges and universities must serve the local economic and social development as the main goal, so the orientation of personnel training, curriculum, teaching objectives, teaching content must be around 
the technology, practice teaching has become the application of technology College teaching part of an important part.

The transformation of local colleges and universities into applied technology colleges and universities, mainly for the local, for the social transport of technical personnel, then the level of practical ability of students directly related to the quality of applied talents training. Therefore, after the transformation of local colleges and universities, it should be employment-oriented, consolidate the practice of teaching.

The transformation of local colleges and universities is the inevitable result of local economic development needs and industrial structure adjustment, and it is also an important strategic measure to solve the shortage of technical skills in China. Practical teaching also plays an important role in students' practical ability, innovation ability and entrepreneurial ability. On the employment of graduates with a strong competitive edge. After the transformation of local colleges and universities, it should be employment-oriented, cultivate local economic development, social development, much-needed talent, practical teaching is a solid foundation.

\section{An Analysis of the Problems in the Practical Teaching of Radio and TV Directing}

The reform of practical teaching curriculum system.Local colleges and universities are based on the college to upgrade to undergraduate, and its development is toward a multidisciplinary, comprehensive, research-oriented direction, theoretical teaching has always occupied the dominant position. Radio and television director is also based on the theory of teaching, practice teaching, supplemented by the existence of theoretical knowledge of the proportion of learning is too large, the proportion of practical teaching is too small, so that students learn too much theoretical knowledge, practice too little, students in a certain The degree of theory and practice out of touch, practical ability is not strong, do not meet the needs of the talent market.

The proportion of teachers and students are not coordinated.With the continuous expansion of the scale of enrollment in recent years, the number of students increased a lot, but the number of professional teachers can not keep up, the current local college radio and television director of professional courses are mostly a teacher on a course, Then this course is the practice of this class is a teacher corresponding to a grade of more than 100 people to explain the guidance, so that teachers can not be carried out by the students on a targeted practical guidance, students shoot out the quality of the work is not high, The late revision of the teacher can not be guided one by one, so the final works reach a certain level, so easy to combat the enthusiasm of students to learn.

The lack of technical ability of professional practice teachers.Radio and television professional teaching in the professional needs of teachers with strong professional practice ability, but many professional teachers are directly after graduation to work directly from the classroom into the classroom, and did not really work in the media industry, their own The theory of learning has not been applied to practice, so the media industry in the specific working environment, work links and content on the lack of knowledge, teachers practice their own teaching ability is not strong, it is difficult to cultivate the application of social skills talents.

Lack of practical teaching platform.Practical teaching platform is mainly outside the practice base. Local colleges and universities radio and television director of professional students in the third year of the year of professional internships, trainees, local colleges and universities generally tend to assign students to the practice base outside the school, that is, to television stations, media companies internship internship, or extracurricular establishment of some school group work Room to attract interested students to participate in practice, but this professional practice practice are fancy, can not let students on their future career has a deep experience, while the extracurricular school group in the teaching content are Idealized, is a simulation of the reality project, can not really make the classroom teaching itself and social practice really together. But also because of the lack of practical operation of the base of the base and sharing mechanism, did not play the practical base of the utility, and some even in name only. 


\section{Radio and Television Playwright-director Professional Practice Teaching Development Strategy}

Perfect the course system, increase the practice course.The cultivation of the original scheme of curriculum structure in the large proportion theory, practice class proportion is small. Local university, 2017 edition.

Training solutions to the existing curriculum structure adjustment, perfect curriculum system. Also organized television personnel according to the aim of training applied talents together to discuss the curriculum, adjust the course structure, reduce the theory courses, increasing practice course. Under the background of the transformation, according to industry status, market development and so on carries on the redesign of undergraduate talent training scheme, more practical courses, highlight the practical teaching link, extend the practice time, in order to better develop the local economy, social development needs of technical persons.

To strengthen the construction of teaching staff.Faculty is broadcasting television playwright-director professional personnel training level is an important link, the construction of teaching staff to the cultivation of applied talents play a vital role.

The introduction of highly educated personnel. By introducing, training, external effective measures, such as quantity and structure, further optimize the teachers troop construction of a reasonable structure, advanced concept, high quality, as well as the combination of solecism, adapt to the applied talents training of teachers, at or near to student/teacher ratio now.

Radio and television playwright-director professional teacher should "go out", to make up the professional development of radio, film and television is closely related to the unit internship, rich practical experience. Participate in professional communication and exchange of TV media industry, domestic and foreign outstanding university, widen our sight.

Professional technical teachers, local universities should consider industry elite, and to teaching, can also do a lecture on a regular basis. Such not only can help students practical understanding of a line of work environment, requirements and work content, also can help students to learn the professional theoretical knowledge and practical skills to better together, become a real application of skilled talents.

Strengthen the "double double type" teachers' training, can double double type teachers have a solid theoretical foundation and has a high level of professional practice teaching skills, can not only in theory, and practice teaching guidance into the line, can speak can do, theory with practice to realize the transformation of teachers' development.

The joint school, after-school practice resources, build a training platform.Broadcasting television playwright-director professional is a practical applied talents training, talents cultivation without years of training platform becomes empty void.

Using the campus radio station, and cultivate the students' practical ability .Using the existing campus radio, in local colleges for more professional teachers to lead students into the campus television station column building work, make the professional teachers can directly apply finish teaching theoretical knowledge to let the students to practice teaching.

Constructing university-enterprise cooperation, achieve profound fusion .Baicheng normal college in recent years, successively with baicheng radio and television stations, 12 stations, television stations such as jilin province education television station and a number of film and television media company has established good relations of cooperation, make full use of the school, industry and so on the many kinds of different environment and education resources, students had learned, on the basis of the organic combination of theory and practice to make the students in the university four years of study in the process of personal comprehensive quality and professional ability get all-round development, for the students practice has provided a broad platform for the practice. In fact, the role of cooperation between higher vocational colleges is to make the school set up the course system, teaching contents, practice teaching, can full range with enterprise requirements, the cultivated students can serve the society directly.

Establish company, entrepreneurship and practice provide simulation platform for the students .Broadcasting television playwright-director professional graduates mainly to television, 
radio, television production units at all levels, all enterprises and institutions, such as network media company propaganda planning and other departments engaged in radio and television, film and television creation, text writing, screenwriter, director, interviews, post-production, etc. Baicheng normal college, therefore, encourage and support the media college students founded the company, according to the entity model to carry out the practice of professional training, let the students can have long into the workplace, be familiar with the work environment and job requirement in advance, broadcasting television playwright-director professional personnel training mode innovation.

Strengthen the production-study-research cooperation in running schools .Transformation of colleges and universities for application technology in colleges and universities, industry oriented, industry oriented, market oriented degree is higher. Therefore, colleges and universities should seek out a variety of ways, to the road of cooperation in running schools, vigorously implement the open education, strengthen the manufacture-learning-research cooperation, actively seeking social support, enterprise, industry and so on, as a practical teaching base, broadcasting television playwright-director professional practice teaching base building is not only to establish good relations of cooperation with the media industry, but also involve personnel Omani-directional in talent training. Expanding between intercollegiate, university-enterprise cooperation in running schools, such as training really meets the needs of local economic development applied technological talents.

\section{Conclusion}

Under the background of the transformation, broadcasting television playwright-director professional practice teaching is facing great challenge, also faced with opportunities at the same time, we should adapt to changing times, grasp the direction, train can meet the demand of local economic development to adapt to the era of broadcasting television playwright-director professional applied talents.

\section{Acknowledgments}

This work was supported by the "Under the Background of Transformation of Colleges and Universities Make the Construction of a Professional Practice Teaching System of Radio, Film and Television Research” (jilin province education science research project, No.16366 ) in part. The author would also like to thank the reviewers for their corrections and helpful suggestion.

\section{References}

[1] Xiao Pan. Transformation under the Background of Local Undergraduate Colleges and Universities of the Reform of Practice Teaching System and Design[J]. Science and Technology Economic Tribune, 2015 (06);

[2]Xu Qinghe. Under the Background of Transformation of Local Colleges Development Practice Teaching Base Construction [J]. The Experiment Technology and Management,2017(1);

[3]Chen Liang.Theory of Transformation of the Local Undergraduate Universities under the Background of Teacher Professional Development Path Optimization [J]. Teacher Education Research, 2015 (12);

[4]Lei Zhenxiang. Under the Background of Transition of the Local Undergraduate Universities Young Teacher Development Path Selection[J].Journal of Heilongjiang Province Ecological Engineering Vocational College, 2016 (07);

[5]Gao Xuechun. Transformation under the Background of Local University Teachers' Ability of the Practical Teaching Strategy Research [J]. Tongren College Journal ,2015(11).

[6]Xu Xiaojuan. In the Local Teaching Reform under the Background of Transition and Development in Colleges and Universities Undergraduate Course Graduation Thesis Research [J]. Guangdong Chemical,2016(10). 